\title{
TWIN BARGE-SPAR HYDRODYNAMIC INTERACTION ON FLOATOVER DECK INSTALLATION
}

\author{
Fahmy Ardhiansyah ${ }^{1}$ dan Norman Mahdar Sabana ${ }^{2}$ \\ ${ }^{1}$ Master Student in Department of Naval Architecture and Shipbuilding Engineering, ITS Surabaya \\ ${ }^{2}$ Master Student in Department of Ocean Engineering, ITS Surabaya \\ Email: fahmyardhiansyah@gmail.com
}

Diterima: 1 Nopember 2016; Direvisi: 10 Nopember 2016; Disetujui: 1 Desember 2016

\begin{abstract}
Abstrak
Jurnal ini berisi tentang instalasi floatover sebuah heavy weight topside deck pada fasilitas terapung minyak dan gas. Dalam penelitian ini bangunan apung yang ditinjau adalah SPAR dengan diameter $25 \mathrm{~m} x$ tinggi $100 \mathrm{~m}$ dan $5 \mathrm{~m}$ sarat air yang akan ditempatkan pada lokasi tertentu dengan tinggi gelombang signifikan (Hs) mencapai 3 meter, periode gelombang (Tp) bervariasi antara $6 \mathrm{~s}$ sampai $10 \mathrm{~s}$, kecepatan arus $0.4 \mathrm{~m} / \mathrm{s}$, dan kecepatan angin 26 knots. Dengan pendekatan teknis secara benar maka konsep instalasi floatover dapat dilakukan daripada menggunakan metode instalasi heavy lift. Analisa floatover telah dilakukan menggunakan perangkat lunak MOSES dan hasilnya menunjukkan jenis instalasi ini dapat dikerjakan sebagai alternatif yang bagus untuk instalasi topside pada fasilitas terapung lepas pantai. Hasil untuk kondisi ekstrem saat instalasi menunjukkan nilai maksimum RMS roll, pitch, dan heave adalah 1.11 degree, 1.13 degree, dan $0.057 \mathrm{~g}$ secara berurutan. Nilai maksimum tersubut terjadi saat tahap instalasi docking stage.
\end{abstract}

Kata kunci: Interaksi Hidrodinamis, Floatover, Instalasi Deck

\begin{abstract}
This paper presents floatover installation of heavy weight topside deck onto floating oil \& gas platform. In this study the floating structure considered was a $25 \mathrm{~m}$ diameter $x 100 \mathrm{~m}$ SPAR hull with 5 meter draft that would be located in specified sea state with significant wave height (Hs) is up to 3.0 meter, peak period (Tp) is varied 6s to $10 \mathrm{~s}, 0.4 \mathrm{~m} / \mathrm{s}$ surface current speed, and 26 knots wind speed condition. With an appropriate technically justification, floatover concept has been carried on instead of heavy lift installation method. The floatover analysis is done by utilizing MOSES suite program, and the result shown this kind of installation method could be done as a good option for install a topside structure of a floating facility in offshore. The results for extreme installation condition show that the maximum RMS roll, pitch, and heave is 1.11 degree, 1.13 degree, and $0.057 \mathrm{~g}$ respectively. Thus maximum results occurred during docking stage installation.
\end{abstract}

Keywords: Hydrodynamic Interaction, Floatover, Deck Installation

\section{INTRODUCTION}

The facility discussed in this paper is to be located in Eastern Indonesian water namely South Arafuru Sea. It's about approximately $500 \mathrm{~km}$ away north from, northern Australia, Darwin. Hydrocarbon field development would be develop by INPEX as part of ABADI field development. At the moment the issue are still focused in FLNG (Floating Liquefied Natural
Gas) facility. In near future the issued should spread to support this field development. The author think is a good to study for another development options, especially by using of SPAR hull to support of field development. Main focused within this study is discussed regarding floatover deck installation method.

SPAR hull will be located in deep water where the kinds of floating facility should be install. The water 
depth at the SPAR location is approximately 600 meter. By looking the field location layout its can be categorized that this area is an open water which is the proposed location shall have affected by Indian Ocean. The topside weight was estimated at 20,000 tons at this initial study. With this condition, a proper selection of installation method which is technically and economically favorable became a great challenge.

In 2006, the first floatover deck was installed on a Spar platform: the Kikeh Spar. This installation was performed in $1320 \mathrm{~m}$ water depths in the South China Sea, offshore East Malaysia. The deck weight was 4000 tons and the swell at the time of installation was $\mathrm{Hs}$ of $0.7 \mathrm{~m}$ at periods of $7-8$ seconds. This was also the first catamaran type floatover performed in open waters (D. Edelson et.al, 2008).

At the another side in the South China Sea, this would be the first time to install a topside over 20,000 tons, for float-over, this would be the first time to install a topside with such heavy weight in an open water area with a near 200 meter water depth worldwide. Therefore, the study needed to answer the questions whether the topside is feasible to be installed by either lifting or float-over method, and any potential existing risk shall be resolved (Jinlin et.al, 2013).

\section{RESEARCH OBJECTIVE}

The research objective is to determine the hydrodynamic interaction between installation barge and spar floating facility during floatover deck installation operation. With a proper hydrodynamic interaction response, designer will recognize the highest response from several floatover installation stages

\footnotetext{
ANALYSIS METHODOLOGY

Offshore platforms are manufactured in fabrication yards and then transported to their offshore site location for installation. Topside deck structures are installed above jacket / spar structures using either heavy lift or float-over methods. Heavy lifting installations are always constrained by the capacity of the heavy lifting barges and their availability, which makes them uneconomical for heavy deck installations. Float-over provides an attractively cost effective way to install offshore decks, especially when the deck weight exceeds available crane lifting capacity (Khaled et.al, 2014).
}

PETROFAC (2016) has been carried on regarding the economical point of view comparing the installation method between floatover and heavy lift. The items to be compared are maximum capacity, hull weight, and so on to specialized engineering requirement. It can be noted that the floatover method need relatively high in engineering but can reduce cost consumption, in the opposite site the heavy lift vessel method is no need of engineering with a high cost consumption.

Dockwise marine contractor has been evaluated the past floatover operation in order to develop new concept for a proposed an installation vessel (Dockwise, 2008). The present pontoon barge method are have some prospect and constraint. The prospect are no slot required for fixed jacket, suitable for SPAR buoys, one successful installation for fixed jacket by ODL for Corocoro WHP project, one successful installation for Kikeh SPAR project by Technip. And the constraint are required a transfer operation prior to installation and not suitable for long distance sea voyage under pontoon barge configuration.

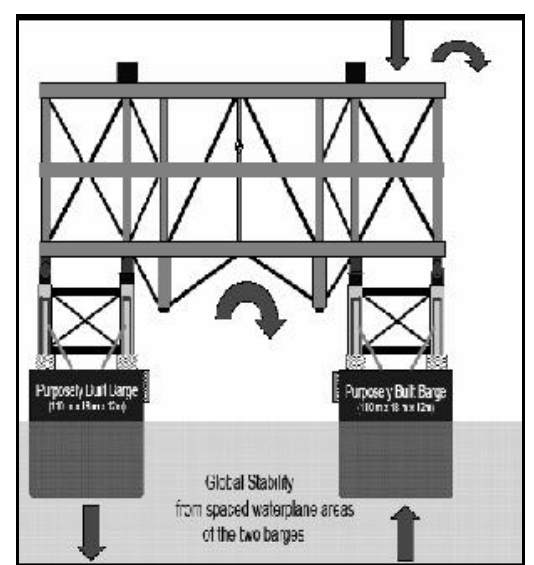

Figure 1. Proposed Installation Barge Size of: $110 \mathrm{~m} \mathrm{x}$ $18 \mathrm{~m} \mathrm{x} 12 \mathrm{~m}$

Figure 1 shows the proposed installation barge to fulfill current floatover challenges. Pontoon barge improvements method are means to loadout directly onto two pontoon barges at fabrication yard; purposely built pontoon barges; suitable for transportation under harsh environments; suitable for both fixed and floating platforms.

The floatover installation are limited by the maximum allowable loads acting at the topside deck and substructure stabbing points, also the Leg Mating 
Unit (LMU), Deck Support Structure (DSU), mooring system, and interface between barge and substructure. Significant wave height (Hs) and peak period (Tp) are the most importance for workability calculation. The calculations of the allowable sea-state condition should consider the following effects: wave height and period, direction of wave and sea swells, seasonal and tidal effects.

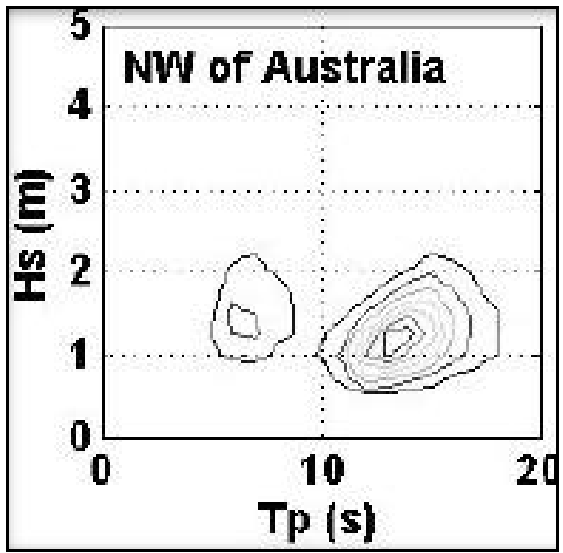

Figure 2. Distribution of Hs and Tp (W.Zhang et.al, 2013)

Since Arafuru Sea is close to NW of Australia and the lack of official Metocean data in this study, so Author would apply this weather data as the study parameter. As seen the distribution of $\mathrm{Hs}$ and $\mathrm{Tp}$ in NW of Australia has a wide range of period, almost more than $10 \mathrm{~s}$, ranging from $10 \mathrm{~s}$ to $19 \mathrm{~s}$. The ranging of wave height are from $0.8 \mathrm{~m}$ to $2.3 \mathrm{~m}$. Therefore, this field are categorized as swell environments locations. As kind of swell environments has some critical factor that shall be consider during mating operation.

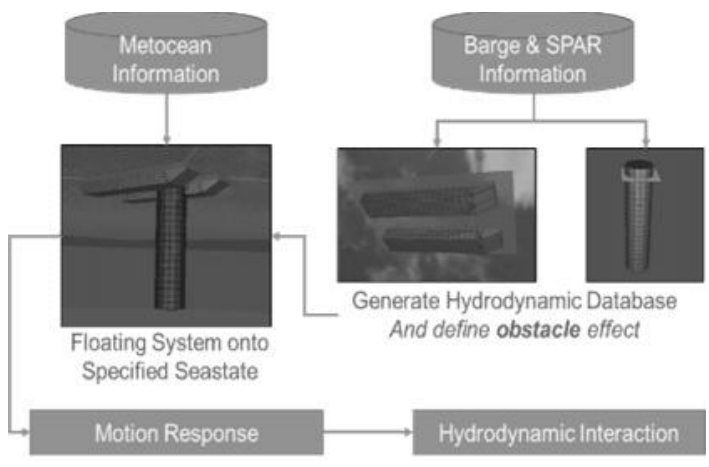

Figure 3. Hydrodynamic Interaction Analysis Methodology
In this study analysis methodology was adopted from J.Ray McDrmott engineering (Kocaman, 2008). In the analysis of the floatover operation, the vessel motions and the resulting loads in the LMU, DSU, and mooring lines need to be estimated. For most motion analysis software the vessel hull needs to be defined as a collection of panel plates. The topsides can be modeled as a rigid body. The program needs to have means to connect the topsides and the vessel using rigid and flexible connector members, as well as the mooring lines. The analysis program then has to put all the components together:

1. The barge will be connected to the seafloor by mooring wires

2. The barge will be connected to the jacket using mating lines, or fenders if a tight slot method is being considered

3. The topsides will be connected to the barge using rigid connecter simulation

4. DSU will contain vertical gap spring and lateral spring element to simulate a frictional surface between the topsides and the barge

5. The topsides will be connected to the jacket using LMUs

6. LMUs will have a nonlinear gap spring element considering mating cone and receptor geometry and ability to generate side loads.

To predict the motions and related connector loads, 3D time domain analysis can be used, modeling the floatover system as three independent rigid bodies with different types of connectors. For the hydrodynamic calculation, 3D diffraction method is applicable. Figure 3 is presented the general methodology to obtained hydrodynamic interaction.

By applying wave, wind, and current environment, the motions of the bodies under study (in this case, the floatover vessel and the topsides) and the forces in the connectors can be predicted. Statistical analysis of the results provide the upper, lower, and nominal values and, thereby, the design basis.

SPAR main dimension is $25 \mathrm{~m}$ diameter $\mathrm{x} 100 \mathrm{~m}$ depth by $95 \mathrm{~m}$ draft, as seen in Figure 4 shows the two stages to be analyzed in this paper. The floatover scenario are taken in to two stages, first is docking stage and the second stage is mating stage. These two condition is believed the most critical phase in floatover installation method. Effective and efficiency of time consuming of numerical simulation also one of the consideration when take this two stages selection. 


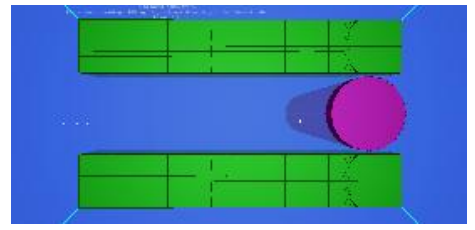

(a) Top View of Docking Stage

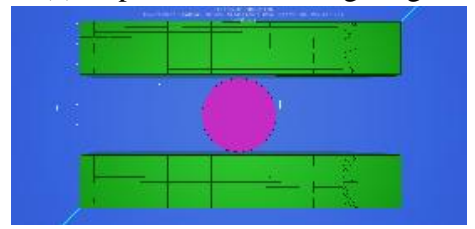

(b) Top View of Mating Stage

Figure 4. Two Stages to be considered in Numerical Analysis

Forty-five (45) loadcases to be computed for each stage, its mean the total loadcases is ninety (90) loadcases to be computed for two stages that considered in analysis. The loadcase is combination of significant wave height (Hs), heading angles, and peak period (Tp). The significant wave height are varied by $1 \mathrm{~m}, 2 \mathrm{~m}$, and $3 \mathrm{~m}$. Then the heading angles increment is $45 \mathrm{deg}$ from following sea, quarter-stern sea, beam-sea, quarter-bow sea, and head sea of barge respectively. And the last combination in wave peak period (Tp) varied from $6 \mathrm{~s}, 8 \mathrm{~s}$, and $10 \mathrm{~s}$.

\section{RESULT AND DISCUSSION}

An extracted result for relative heave motion between barge and SPAR when wave coming from beam is presented in Figure 5. In those figure several relative motion is presented by significant wave height 1 meter, 2 meter, and 3 meter respectively. As expected the highest response is occurred when the significant wave height is high as well. Furthermore the relative heave motion when wave coming from bow is presented in Figure 6 by significant wave height 1 meter, 2 meter, and 3 meter respectively.

In this floatover analysis obtain a result that present the floating system response during docking stage and mating stage of floatover installation process. From the results indicated that highest response occurred in docking stage rather than mating stage. However the difference between those two is has slight difference. More result are presented in Table 1 and Table 2 for docking stage and mating stage respectively. As a sample the twin barge maximum RMS roll motion during docking stage is 1.11 degree, compare to mating stage is 1.02 degree.

In summary we now can conclude, from hydrodynamic interaction simulation it's obtained the vertical motion for mating stage as below: The heave acceleration is present in unit of $g$ (gravity) rather than $\mathrm{m} / \mathrm{s} 2$, which $1 \mathrm{~g}$ is equal to $9.81 \mathrm{~m} / \mathrm{s} 2$.

A. Docking Stage

- $\mathrm{Hs}=1$ meter

Maximum RMS Roll (degree) $\quad=0.390$

Maximum RMS Pitch (degree) $\quad=0.370$

Maximum RMS Heave $(\mathrm{g}) \quad=0.020$

- $\mathrm{Hs}=2$ meter

Maximum RMS Roll (degree) $\quad=0.760$

Maximum RMS Pitch (degree) $\quad=0.750$

Maximum RMS Heave $(\mathrm{g}) \quad=0.038$

- $\mathrm{Hs}=3$ meter

Maximum RMS Roll (degree) $\quad=1.110$

Maximum RMS Pitch (degree) $\quad=1.130$

Maximum RMS Heave $(\mathrm{g}) \quad=0.057$

B. Mating Stage

- $\mathrm{Hs}=1$ meter

Maximum RMS Roll (degree) $\quad=0.350$

Maximum RMS Pitch (degree) $\quad=0.370$

Maximum RMS Heave $(\mathrm{g}) \quad=0.017$

- $\mathrm{Hs}=2$ meter

Maximum RMS Roll (degree) $\quad=0.690$

Maximum RMS Pitch (degree) $\quad=0.740$

Maximum RMS Heave $(\mathrm{g}) \quad=0.034$

- $\mathrm{Hs}=3$ meter

Maximum RMS Roll (degree) $\quad=1.020$

Maximum RMS Pitch (degree) $\quad=1.120$

Maximum RMS Heave $(\mathrm{g}) \quad=0.052$
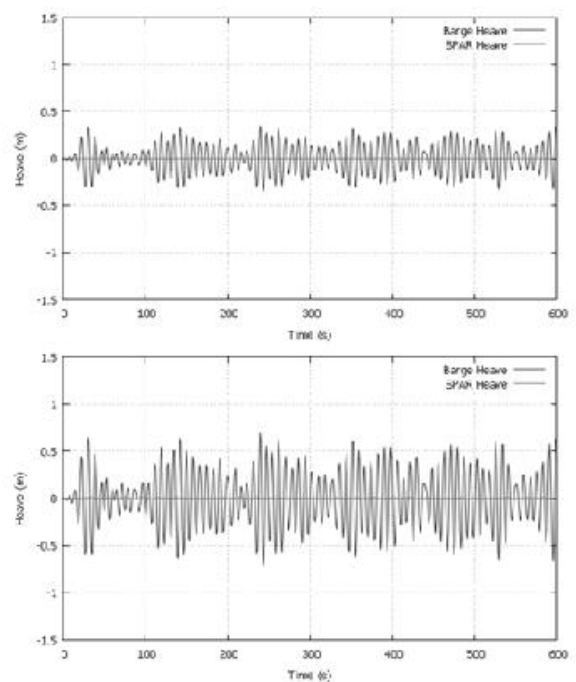


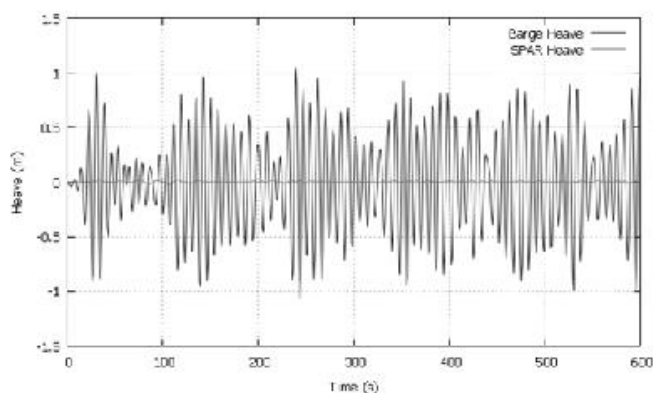

Figure 5. Relative Heave Motion Wave Coming

from Beam
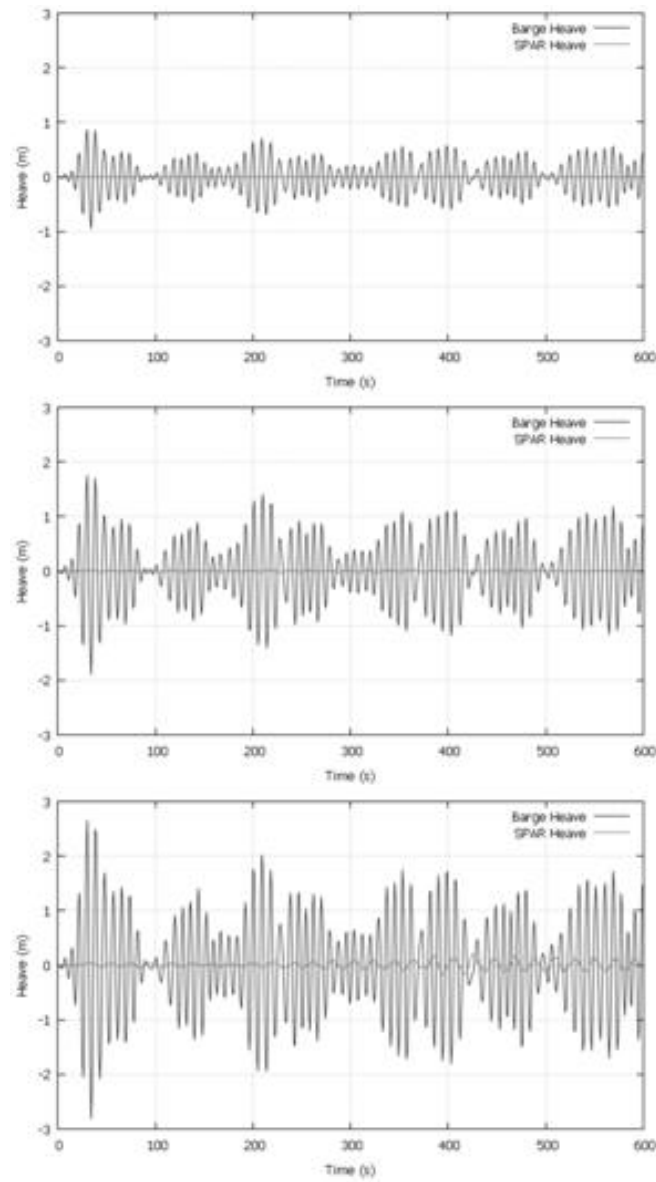

Figure 6. Relative Heave Motion Wave Coming

from Bow.

As expected the result indicated that installation process would be better for lower significant wave height condition. In term of motion response of floating structure, all results are seem good due to the maximum roll, pitch, and roll motion is quite small even in rough environment $\mathrm{Hs}=3.0 \mathrm{~m}$. However in term of structural integrity of topside structure and LMU in the SPAR hull, its need to do further study for the structural strength itself.

The floatover analysis is done by utilizing MOSES suite program, and the result shown this kind of installation method would be a good option for install a topside structure of a floating facility in offshore.

\section{CONCLUSION}

Finally now we conclude that a twin barge installation vessel for SPAR topside deck is a good option for floatover offshore operation instead of using heavy lift vessel which is consequences in costly operation.

The performance of twin barge has been numerically investigated using MOSES software package and proved that this method has a wider operability sea state.

\section{ACKNOWLEDGEMENT}

Author would like to thanks to the Bentley Engineering Inc. for provide an academic license of MOSES software to ITS Surabaya for academic and research purpose

\section{REFERENCES}

D. Edelson, M. Luo, J. Halkyard, D. Smiley. (2008). Kikeh Development: Spar Topside Floatover Installation. OTC 19639.

Dockwise. (2008). Float-Overs: What's Present and What's Next.

Jinlin Hou, Qian (Ken)Tang and Lian Xu. (2013). Installation Method Selection for Heavy Weight Topside in the South China Sea. ISOPE.

Khaled A. Geba , Yousri M. A. Welaya, Heba W. Leheta and Yehia A. Abdel-Nasser. (2014). Motion and Structural Analysis of Floaters Float-over during the Mating Operation. ISOPE.

Kocaman, Alp. (2008). Overcoming Float-Over Challenges. Offshore Magazine, 68.

PETROFAC. (2016). Floatover Installation -Overcoming the Constraints.

W. Zhang, P.E., C. Jeong, Ph. D., A.v. Spreeken, . (2013). Float-over Feasibility in Brazilian Sea Water. OTC 24304. 
Table 1. Motion Response at Docking Stage

\begin{tabular}{|c|c|c|c|c|c|c|c|c|c|c|c|c|c|c|c|c|}
\hline \multirow{3}{*}{ Run } & \multirow{3}{*}{$\begin{array}{l}\mathrm{Hs} \\
(\mathrm{m})\end{array}$} & \multirow{3}{*}{$\begin{array}{c}\text { heading } \\
\text { (deg) }\end{array}$} & \multirow{3}{*}{\begin{tabular}{|c|} 
Period \\
(s) \\
\end{tabular}} & \multicolumn{6}{|c|}{ RMS Motion of Twin Barge } & \multicolumn{7}{|c|}{ RMS Acceleration of Twin Barge } \\
\hline & & & & \multirow{2}{*}{$\frac{X}{(m)}$} & \multirow{2}{*}{$\begin{array}{c}\mathrm{Y} \\
(\mathrm{m})\end{array}$} & \multirow{2}{*}{$\frac{Z}{(m)}$} & \multirow{2}{*}{$\begin{array}{c}\text { RX } \\
\text { (deg) }\end{array}$} & \multirow{2}{*}{$\begin{array}{c}\text { RY } \\
(\operatorname{deg})\end{array}$} & \multirow{2}{*}{$\begin{array}{c}\text { RZ } \\
\text { (deg) }\end{array}$} & \multirow{2}{*}{$\frac{A-X}{\left(m \cdot s^{-2}\right)}$} & \multirow{2}{*}{$\frac{\text { A-Y }}{\left(m \cdot s^{-2}\right)}$} & \multicolumn{2}{|c|}{$\mathrm{A}-\mathrm{Z}$} & \multirow{2}{*}{\begin{tabular}{|c|}
$\mathrm{A}-\mathrm{RX}$ \\
$\left(\operatorname{rad} . \mathrm{s}^{-2}\right)$ \\
\end{tabular}} & & A-RZ \\
\hline & & & & & & & & & & & & $\left(\mathrm{m} \cdot \mathrm{s}^{-2}\right)$ & (g) & & $\left(\right.$ rad. $\left.s^{-2}\right)$ & $\left(\right.$ rad. $\left.s^{-2}\right)$ \\
\hline 1 & & & 6 & 9.73 & 0.00 & 0.01 & 0.00 & 0.31 & 0.00 & 0.04 & 0.00 & 0.17 & 0.017 & 0.00 & 0.19 & 0.00 \\
\hline 2 & & 0 & 8 & 9.05 & 0.00 & 0.01 & 0.00 & 0.34 & 0.00 & 0.05 & 0.00 & 0.17 & 0.017 & 0.00 & 0.17 & 0.00 \\
\hline 3 & & & 10 & 9.76 & 0.00 & 0.01 & 0.00 & 0.28 & 0.00 & 0.04 & 0.00 & 0.12 & 0.012 & 0.00 & 0.12 & 0.00 \\
\hline 4 & & & 6 & 10.41 & 0.01 & 0.01 & 0.08 & 0.22 & 0.00 & 0.03 & 0.01 & 0.12 & 0.012 & 0.06 & 0.14 & 0.00 \\
\hline 5 & & 45 & 8 & 8.59 & 0.02 & 0.01 & 0.12 & 0.23 & 0.00 & 0.04 & 0.01 & 0.14 & 0.014 & 0.05 & 0.12 & 0.00 \\
\hline 6 & & & 10 & 9.49 & 0.02 & 0.01 & 0.14 & 0.19 & 0.00 & 0.04 & 0.01 & 0.10 & 0.010 & 0.05 & 0.08 & 0.00 \\
\hline 7 & & & 6 & 0.94 & 0.07 & 0.00 & 0.39 & 0.04 & 0.00 & 0.01 & 0.05 & 0.10 & 0.010 & 0.31 & 0.03 & 0.00 \\
\hline 8 & 1 & 90 & 8 & 4.13 & 0.06 & 0.00 & 0.34 & 0.06 & 0.00 & 0.01 & 0.03 & 0.07 & 0.007 & 0.20 & 0.03 & 0.00 \\
\hline 9 & & & 10 & 3.36 & 0.05 & 0.00 & 0.30 & 0.05 & 0.00 & 0.01 & 0.03 & 0.06 & 0.006 & 0.14 & 0.02 & 0.00 \\
\hline 10 & & & 6 & 10.47 & 0.03 & 0.01 & 0.16 & 0.21 & 0.00 & 0.03 & 0.03 & 0.15 & 0.015 & 0.15 & 0.14 & 0.00 \\
\hline 11 & & 135 & 8 & 8.64 & 0.03 & 0.01 & 0.15 & 0.29 & 0.00 & 0.04 & 0.02 & 0.13 & 0.013 & 0.10 & 0.14 & 0.00 \\
\hline 12 & & & 10 & 5.01 & 0.03 & 0.01 & 0.16 & 0.24 & 0.00 & 0.04 & 0.01 & 0.10 & 0.010 & 0.07 & 0.09 & 0.00 \\
\hline 13 & & & 6 & 10.54 & 0.00 & 0.01 & 0.00 & 0.25 & 0.00 & 0.03 & 0.00 & 0.19 & 0.019 & 0.00 & 0.16 & 0.00 \\
\hline 14 & & 180 & 8 & 9.49 & 0.00 & 0.01 & 0.00 & 0.37 & 0.00 & 0.05 & 0.00 & 0.17 & 0.017 & 0.00 & 0.17 & 0.00 \\
\hline 15 & & & 10 & 6.62 & 0.00 & 0.01 & 0.00 & 0.31 & 0.00 & 0.05 & 0.00 & 0.12 & 0.012 & 0.00 & 0.12 & 0.00 \\
\hline 16 & & & 6 & 12.60 & 0.00 & 0.02 & 0.00 & 0.62 & 0.00 & 0.07 & 0.00 & 0.33 & 0.034 & 0.00 & 0.39 & 0.00 \\
\hline 17 & & 0 & 8 & 12.01 & 0.00 & 0.04 & 0.00 & 0.68 & 0.00 & 0.10 & 0.00 & 0.34 & 0.035 & 0.00 & 0.33 & 0.00 \\
\hline 18 & & & 10 & 12.27 & 0.00 & 0.03 & 0.00 & 0.56 & 0.00 & 0.09 & 0.00 & 0.24 & 0.025 & 0.00 & 0.23 & 0.00 \\
\hline 19 & & & 6 & 12.98 & 0.03 & 0.02 & 0.15 & 0.44 & 0.00 & 0.06 & 0.02 & 0.23 & 0.024 & 0.13 & 0.27 & 0.00 \\
\hline 20 & & 45 & 8 & 12.03 & 0.04 & 0.03 & 0.24 & 0.47 & 0.00 & 0.08 & 0.02 & 0.28 & 0.028 & 0.11 & 0.24 & 0.00 \\
\hline 21 & & & 10 & 12.20 & 0.05 & 0.03 & 0.28 & 0.39 & 0.00 & 0.07 & 0.02 & 0.20 & 0.021 & 0.09 & 0.17 & 0.00 \\
\hline 22 & & & 6 & 3.66 & 0.13 & 0.01 & 0.76 & 0.09 & 0.01 & 0.02 & 0.10 & 0.20 & 0.020 & 0.59 & 0.06 & 0.01 \\
\hline 23 & 2 & 90 & 8 & 10.08 & 0.12 & 0.01 & 0.67 & 0.13 & 0.01 & 0.02 & 0.07 & 0.14 & 0.015 & 0.39 & 0.06 & 0.01 \\
\hline 24 & & & 10 & 9.22 & 0.10 & 0.02 & 0.59 & 0.09 & 0.01 & 0.01 & 0.05 & 0.12 & 0.013 & 0.28 & 0.04 & 0.00 \\
\hline 25 & & & 6 & 13.16 & 0.05 & 0.02 & 0.31 & 0.42 & 0.00 & 0.07 & 0.05 & 0.30 & 0.031 & 0.29 & 0.28 & 0.00 \\
\hline 26 & & 135 & 8 & 11.68 & 0.05 & 0.03 & 0.30 & 0.57 & 0.00 & 0.09 & 0.03 & 0.26 & 0.026 & 0.19 & 0.27 & 0.00 \\
\hline 27 & & & 10 & 9.70 & 0.05 & 0.03 & 0.31 & 0.47 & 0.00 & 0.08 & 0.02 & 0.19 & 0.019 & 0.14 & 0.19 & 0.00 \\
\hline 28 & & & 6 & 13.33 & 0.00 & 0.03 & 0.00 & 0.49 & 0.00 & 0.06 & 0.00 & 0.38 & 0.038 & 0.00 & 0.32 & 0.00 \\
\hline 29 & & 180 & 8 & 12.48 & 0.00 & 0.04 & 0.00 & 0.75 & 0.00 & 0.10 & 0.00 & 0.34 & 0.035 & 0.00 & 0.35 & 0.00 \\
\hline 30 & & & 10 & 10.17 & 0.00 & 0.04 & 0.00 & 0.63 & 0.00 & 0.09 & 0.00 & 0.24 & 0.024 & 0.00 & 0.24 & 0.00 \\
\hline 31 & & & 6 & 13.56 & 0.00 & 0.05 & 0.00 & 0.93 & 0.00 & 0.11 & 0.00 & 0.50 & 0.051 & 0.00 & 0.58 & 0.00 \\
\hline 32 & & 0 & 8 & 11.26 & 0.00 & 0.08 & 0.00 & 1.04 & 0.00 & 0.15 & 0.00 & 0.52 & 0.053 & 0.00 & 0.51 & 0.00 \\
\hline 33 & & & 10 & 13.29 & 0.00 & 0.07 & 0.00 & 0.84 & 0.00 & 0.14 & 0.00 & 0.37 & 0.038 & 0.00 & 0.36 & 0.00 \\
\hline 34 & & & 6 & 14.66 & 0.04 & 0.04 & 0.23 & 0.67 & 0.00 & 0.09 & 0.03 & 0.35 & 0.036 & 0.19 & 0.41 & 0.00 \\
\hline 35 & & 45 & 8 & 11.57 & 0.06 & 0.07 & 0.36 & 0.72 & 0.01 & 0.13 & 0.03 & 0.42 & 0.043 & 0.16 & 0.36 & 0.01 \\
\hline 36 & & & 10 & 13.15 & 0.07 & 0.06 & 0.42 & 0.59 & 0.01 & 0.11 & 0.02 & 0.31 & 0.031 & 0.14 & 0.25 & 0.00 \\
\hline 37 & & & 6 & 8.28 & 0.20 & 0.02 & 1.11 & 0.13 & 0.02 & 0.04 & 0.15 & 0.30 & 0.030 & 0.86 & 0.08 & 0.02 \\
\hline 38 & 3 & 90 & 8 & 11.35 & 0.18 & 0.03 & 1.00 & 0.19 & 0.02 & 0.02 & 0.10 & 0.22 & 0.022 & 0.58 & 0.09 & 0.02 \\
\hline 39 & & & 10 & 11.47 & 0.15 & 0.03 & 0.88 & 0.14 & 0.01 & 0.02 & 0.07 & 0.19 & 0.019 & 0.42 & 0.06 & 0.01 \\
\hline 40 & & & 6 & 14.56 & 0.08 & 0.05 & 0.45 & 0.63 & 0.01 & 0.10 & 0.07 & 0.46 & 0.047 & 0.42 & 0.43 & 0.00 \\
\hline 41 & & 135 & 8 & 12.60 & 0.08 & 0.06 & 0.45 & 0.87 & 0.01 & 0.14 & 0.05 & 0.39 & 0.040 & 0.29 & 0.41 & 0.00 \\
\hline 42 & & & 10 & 11.50 & 0.08 & 0.05 & 0.47 & 0.71 & 0.01 & 0.11 & 0.04 & 0.29 & 0.029 & 0.21 & 0.28 & 0.00 \\
\hline 43 & & & 6 & 14.49 & 0.00 & 0.06 & 0.00 & 0.73 & 0.00 & 0.09 & 0.00 & 0.56 & 0.057 & 0.00 & 0.48 & 0.00 \\
\hline 44 & & 180 & 8 & 13.65 & 0.00 & 0.09 & 0.00 & 1.13 & 0.00 & 0.15 & 0.00 & 0.51 & 0.052 & 0.00 & 0.52 & 0.00 \\
\hline 45 & & & 10 & 12.17 & 0.00 & 0.07 & 0.00 & 0.94 & 0.00 & 0.14 & 0.00 & 0.36 & 0.037 & 0.00 & 0.36 & 0.00 \\
\hline & & & Maximum & 14.66 & 0.20 & 0.09 & 1.11 & 1.13 & 0.02 & 0.15 & 0.15 & 0.56 & 0.057 & 0.86 & 0.58 & 0.02 \\
\hline
\end{tabular}


Twin Barge-SPAR Hydrodynamic Interaction on Floatoaver Deck Installation (Fahmy Ardhiansyah dan Norman Mahdar Sabana)

Table 2. Motion Response at Mating Stage

\begin{tabular}{|c|c|c|c|c|c|c|c|c|c|c|c|c|c|c|c|}
\hline \multirow{3}{*}{$\begin{array}{l}\mathrm{Hs} \\
\text { (m) }\end{array}$} & \multirow{3}{*}{$\begin{array}{c}\text { heading } \\
\text { (deg) }\end{array}$} & \multirow{3}{*}{$\begin{array}{c}\text { Period } \\
\text { (s) }\end{array}$} & \multicolumn{6}{|c|}{ RMS Motion of Twin Barge } & \multicolumn{7}{|c|}{ RMS Acceleration of Twin Barge } \\
\hline & & & \multirow{2}{*}{$\frac{X}{(m)}$} & \multirow{2}{*}{$\frac{\mathrm{Y}}{\mathrm{(m)}}$} & \multirow{2}{*}{$\frac{Z}{\mathrm{Z}}$} & \multirow{2}{*}{$\begin{array}{c}\mathrm{RX} \\
\text { (deg) }\end{array}$} & \multirow{2}{*}{$\frac{\mathrm{RY}}{\text { (deg) }}$} & \multirow{2}{*}{$\begin{array}{c}\text { RZ } \\
\text { (deg) }\end{array}$} & \multirow{2}{*}{$\frac{\mathrm{A}-\mathrm{X}}{\left(\mathrm{m} \cdot \mathrm{s}^{-2}\right)}$} & \multirow{2}{*}{$\frac{A-Y}{\left(m-s^{-2}\right)}$} & \multicolumn{2}{|c|}{ A-Z } & \multirow{2}{*}{$\frac{\mathrm{A}-\mathrm{RX}}{\left(\mathrm{rad} . \mathrm{s}^{-2}\right)}$} & \multirow{2}{*}{$\frac{\mathrm{A}-\mathrm{RY}}{\left(\mathrm{rad} \cdot \mathrm{s}^{-2}\right)}$} & \multirow{2}{*}{$\frac{\mathrm{A}-\mathrm{RZ}}{\left(\mathrm{rad} \cdot \mathrm{s}^{-2}\right)}$} \\
\hline & & & & & & & & & & & $\left(m \cdot s^{-2}\right)$ & (g) & & & \\
\hline & & 6 & 10.56 & 0.00 & 8.00 & 0.00 & 0.17 & 0.00 & 0.02 & 0.00 & 0.07 & 0.008 & 0.00 & 0.09 & 0.00 \\
\hline & 0 & 8 & 10.00 & 0.00 & 8.01 & 0.00 & 0.34 & 0.00 & 0.04 & 0.00 & 0.12 & 0.012 & 0.00 & 0.14 & 0.00 \\
\hline & & 10 & 10.00 & 0.00 & 8.01 & 0.00 & 0.31 & 0.00 & 0.05 & 0.00 & 0.09 & 0.009 & 0.00 & 0.10 & 0.00 \\
\hline & & 6 & 10.38 & 0.01 & 8.00 & 0.07 & 0.16 & 0.00 & 0.03 & 0.01 & 0.12 & 0.012 & 0.06 & 0.11 & 0.00 \\
\hline & 45 & 8 & 9.69 & 0.02 & 8.01 & 0.13 & 0.26 & 0.00 & 0.04 & 0.01 & 0.11 & 0.011 & 0.06 & 0.11 & 0.00 \\
\hline & & 10 & 9.77 & 0.03 & 8.01 & 0.15 & 0.22 & 0.00 & 0.04 & 0.01 & 0.09 & 0.009 & 0.05 & 0.08 & 0.00 \\
\hline & & 6 & 2.19 & 0.06 & 8.00 & 0.35 & 0.11 & 0.00 & 0.01 & 0.05 & 0.10 & 0.010 & 0.28 & 0.09 & 0.00 \\
\hline 1 & 90 & 8 & 5.45 & 0.06 & 8.00 & 0.32 & 0.06 & 0.00 & 0.01 & 0.03 & 0.08 & 0.008 & 0.19 & 0.05 & 0.00 \\
\hline & & 10 & 3.92 & 0.05 & 8.00 & 0.29 & 0.04 & 0.00 & 0.01 & 0.02 & 0.07 & 0.007 & 0.14 & 0.03 & 0.00 \\
\hline & & 6 & 10.00 & 0.02 & 8.01 & 0.09 & 0.17 & 0.00 & 0.03 & 0.01 & 0.13 & 0.013 & 0.08 & 0.12 & 0.00 \\
\hline & 135 & 8 & 8.79 & 0.02 & 8.01 & 0.13 & 0.29 & 0.00 & 0.04 & 0.01 & 0.14 & 0.014 & 0.07 & 0.12 & 0.00 \\
\hline & & 10 & 7.45 & 0.03 & 8.01 & 0.15 & 0.24 & 0.00 & 0.04 & 0.01 & 0.10 & 0.010 & 0.05 & 0.09 & 0.00 \\
\hline & & 6 & 10.28 & 0.00 & 8.01 & 0.00 & 0.19 & 0.00 & 0.02 & 0.00 & 0.14 & 0.014 & 0.00 & 0.12 & 0.00 \\
\hline & 180 & 8 & 9.69 & 0.00 & 8.01 & 0.00 & 0.37 & 0.00 & 0.05 & 0.00 & 0.17 & 0.017 & 0.00 & 0.16 & 0.00 \\
\hline & & 10 & 8.74 & 0.00 & 8.01 & 0.00 & 0.32 & 0.00 & 0.05 & 0.00 & 0.12 & 0.012 & 0.00 & 0.11 & 0.00 \\
\hline & & 6 & 13.20 & 0.00 & 8.00 & 0.00 & 0.33 & 0.00 & 0.04 & 0.00 & 0.15 & 0.015 & 0.00 & 0.19 & 0.00 \\
\hline & 0 & 8 & 12.23 & 0.00 & 8.02 & 0.00 & 0.68 & 0.00 & 0.08 & 0.00 & 0.23 & 0.024 & 0.00 & 0.28 & 0.00 \\
\hline & & 10 & 12.85 & 0.00 & 8.03 & 0.00 & 0.61 & 0.00 & 0.09 & 0.00 & 0.18 & 0.019 & 0.00 & 0.20 & 0.00 \\
\hline & & 6 & 13.16 & 0.02 & 8.01 & 0.14 & 0.31 & 0.00 & 0.05 & 0.02 & 0.24 & 0.024 & 0.11 & 0.22 & 0.00 \\
\hline & 45 & 8 & 12.21 & 0.05 & 8.02 & 0.26 & 0.51 & 0.01 & 0.08 & 0.02 & 0.22 & 0.023 & 0.12 & 0.22 & 0.00 \\
\hline & & 10 & 12.45 & 0.05 & 8.02 & 0.30 & 0.45 & 0.01 & 0.07 & 0.02 & 0.17 & 0.017 & 0.10 & 0.16 & 0.00 \\
\hline & & 6 & 8.50 & 0.12 & 8.01 & 0.69 & 0.21 & 0.01 & 0.03 & 0.10 & 0.20 & 0.021 & 0.54 & 0.17 & 0.01 \\
\hline 2 & 90 & 8 & 9.99 & 0.11 & 8.02 & 0.64 & 0.12 & 0.01 & 0.02 & 0.07 & 0.16 & 0.016 & 0.37 & 0.09 & 0.01 \\
\hline & & 10 & 9.54 & 0.10 & 8.02 & 0.57 & 0.08 & 0.01 & 0.01 & 0.05 & 0.13 & 0.013 & 0.27 & 0.06 & 0.00 \\
\hline & & 6 & 12.80 & 0.03 & 8.02 & 0.18 & 0.35 & 0.00 & 0.06 & 0.03 & 0.26 & 0.026 & 0.16 & 0.24 & 0.00 \\
\hline & 135 & 8 & 10.93 & 0.05 & 8.04 & 0.27 & 0.57 & 0.00 & 0.09 & 0.02 & 0.28 & 0.028 & 0.13 & 0.25 & 0.00 \\
\hline & & 10 & 10.76 & 0.05 & 8.03 & 0.30 & 0.48 & 0.00 & 0.07 & 0.02 & 0.20 & 0.021 & 0.10 & 0.17 & 0.00 \\
\hline & & 6 & 13.12 & 0.00 & 8.03 & 0.00 & 0.39 & 0.00 & 0.05 & 0.00 & 0.28 & 0.028 & 0.00 & 0.25 & 0.00 \\
\hline & 180 & 8 & 12.76 & 0.00 & 8.05 & 0.00 & 0.74 & 0.00 & 0.10 & 0.00 & 0.34 & 0.034 & 0.00 & 0.31 & 0.00 \\
\hline & & 10 & 11.47 & 0.00 & 8.04 & 0.00 & 0.64 & 0.00 & 0.09 & 0.00 & 0.24 & 0.025 & 0.00 & 0.22 & 0.00 \\
\hline & & 6 & 14.49 & 0.00 & 8.01 & 0.00 & 0.50 & 0.00 & 0.06 & 0.00 & 0.22 & 0.022 & 0.00 & 0.28 & 0.00 \\
\hline & 0 & 8 & 14.10 & 0.00 & 8.05 & 0.00 & 1.02 & 0.00 & 0.13 & 0.00 & 0.35 & 0.035 & 0.00 & 0.42 & 0.00 \\
\hline & & 10 & 14.01 & 0.00 & 8.06 & 0.00 & 0.92 & 0.00 & 0.14 & 0.00 & 0.27 & 0.028 & 0.00 & 0.31 & 0.00 \\
\hline & & 6 & 14.50 & 0.04 & 8.02 & 0.21 & 0.47 & 0.00 & 0.08 & 0.03 & 0.36 & 0.037 & 0.17 & 0.33 & 0.00 \\
\hline & 45 & 8 & 13.89 & 0.07 & 8.05 & 0.40 & 0.77 & 0.01 & 0.12 & 0.03 & 0.33 & 0.034 & 0.17 & 0.34 & 0.01 \\
\hline & & 10 & 13.77 & 0.08 & 8.05 & 0.45 & 0.67 & 0.01 & 0.11 & 0.03 & 0.26 & 0.026 & 0.14 & 0.24 & 0.01 \\
\hline & & 6 & 10.41 & 0.18 & 8.02 & 1.02 & 0.32 & 0.02 & 0.04 & 0.14 & 0.31 & 0.031 & 0.79 & 0.26 & 0.02 \\
\hline 3 & 90 & 8 & 11.81 & 0.17 & 8.03 & 0.96 & 0.18 & 0.02 & 0.02 & 0.10 & 0.24 & 0.025 & 0.55 & 0.14 & 0.02 \\
\hline & & 10 & 11.50 & 0.15 & 8.04 & 0.86 & 0.12 & 0.01 & 0.02 & 0.07 & 0.20 & 0.020 & 0.40 & 0.09 & 0.01 \\
\hline & & 6 & 14.09 & 0.05 & 8.05 & 0.27 & 0.52 & 0.00 & 0.08 & 0.04 & 0.38 & 0.039 & 0.23 & 0.36 & 0.00 \\
\hline & 135 & 8 & 13.21 & 0.07 & 8.09 & 0.40 & 0.86 & 0.01 & 0.13 & 0.04 & 0.42 & 0.043 & 0.20 & 0.38 & 0.00 \\
\hline & & 10 & 12.68 & 0.08 & 8.07 & 0.45 & 0.72 & 0.01 & 0.11 & 0.03 & 0.30 & 0.031 & 0.15 & 0.26 & 0.00 \\
\hline & & 6 & 13.99 & 0.00 & 8.06 & 0.00 & 0.58 & 0.00 & 0.07 & 0.00 & 0.41 & 0.042 & 0.00 & 0.37 & 0.00 \\
\hline & 180 & 8 & 14.01 & 0.00 & 8.12 & 0.00 & 1.12 & 0.00 & 0.15 & 0.00 & 0.51 & 0.052 & 0.00 & 0.47 & 0.00 \\
\hline & & 10 & 13.61 & 0.00 & 8.10 & 0.00 & 0.97 & 0.00 & 0.14 & 0.00 & 0.37 & 0.037 & 0.00 & 0.33 & 0.00 \\
\hline & & Maximun & 14.50 & 0.18 & 0,09 & 102 & 112 & 0.02 & 0.15 & 0.14 & 0.51 & 0.052 & 0.79 & 0.47 & 0.02 \\
\hline
\end{tabular}


Jurnal Wave Volume 10 Nomor 2, Desember 2016; Hal: 67-74

[ Halaman Kosong ] 